\title{
Antioxidant, antimicrobial activities and phytochemical analysis of leaves extracts of Dioscorea wallichii Hook. f.
}

\author{
Kokkaiah Irulandi, Sethupandian Geetha, Palanichamy Mehalingam* \\ Research Department of Botany, VHN Senthikumara Nadar College (Autonomous), Virudhunagar, India.
}

\begin{tabular}{|c|c|}
\hline ARTICLE INFO & ABSTRACT \\
\hline Article history: & \multirow{10}{*}{$\begin{array}{l}\text { The present study was carried out to evaluate the phytochemical, antioxidant activity and antimicrobial activity } \\
\text { of leaf of Dioscorea wallichii. The antimicrobial effect of the studied plant was evaluated on the following } \\
\text { bacterial species, Micrococcus mucilaginosus, Escherichia coli, Klebsiella terrigena, Pseudomonas aeruginosa, } \\
\text { Bacillus cereus, Staphyllococcus aureus, and Candida albicans. The solvents used for the extraction were } \\
\text { acetone, ethyl acetate and methanol. The in vitro antimicrobial activity was performed by well diffusion method. } \\
\text { The antimicrobial activities of D. wallichii in successive different solvent were tested against Gram positive and } \\
\text { Gram negative bacteria and fungus. The extracts showed the presence of flavonoids, coumarins, phenols, } \\
\text { tannins, saponins, terpenoids, quinones and catechins. The acetone and methanol extracts of D. wallichii showed } \\
\text { the broad spectrum of antimicrobial activity when compared with positive control. The DPPH assay was also } \\
\text { conducted for methanolic leaf extract exhibited highest activity which is compare to the activity of the ascorbic } \\
\text { acid standard. In conclusion, all organic crude extracts from leaves could be used as potential sources of new } \\
\text { antioxidant and antimicrobial agents. }\end{array}$} \\
\hline Received on: $03 / 08 / 2016$ & \\
\hline Revised on: 07/09/2016 & \\
\hline Accepted on: 10/10/2016 & \\
\hline Available online: $29 / 11 / 2016$ & \\
\hline Keywords: & \\
\hline Dioscorea wallichii, & \\
\hline Phytochemical analysis, & \\
\hline Antioxidant, DPPH, & \\
\hline Antimicrobial activities. & \\
\hline
\end{tabular}

\section{INTRODUCTION}

Medicinal plants are the important source of natural antioxidants. Antioxidants are compounds that protect cells against the damaging effects of reactive oxygen species (ROS) such as superoxide, hydroxyl radicals, singlet oxygen, peroxy radicals etc. These active oxygen species and free radicals can attack molecules in biological membranes and tissues and thus inducing oxidative stress that further has been associated with cancer, ageing, inflammation, neurodegenerative diseases, hypertension, artherosclerosis (Stocker and Keaney, 2004; Devasagayam et al., 2004; Kaur et al., 2007; Grassi et al., 2009). Most of the antioxidant compounds in a typical diet are derived from plant sources and belong to various classes of compounds with a wide variety of physical and chemical properties. The main characteristic of an antioxidant is its ability to trap free radicals (Walton and Brown, 1999).

\footnotetext{
* Corresponding Author

Palanichamy Mehalingam, Research Department of Botany, VHN Senthikumara Nadar College (Autonomous), Virudhunagar, India. Email:mehalingamp@yahoo.co.in
}

The major antioxidants of vegetables are vitamins $\mathrm{C}$ and E, carotenoids and phenolic compounds, especially flavonoids. These compounds present in vegetables contribute free radicals scavenge and inhibit the chain initiation or break the chain propagations give both to the first and second defense lines against oxidative stress. As a result, they protect cells against oxidative damage, and may therefore prevent chronic diseases, such as cancer, cardiovascular disease, and diabetes. Vitamin $\mathrm{E}$ and carotenoids also contribute to the first defense line against oxidative stress, because they quench singlet oxygen (Krinsky, 2001; Shi et al., 2001).

Free radicals cause several disorders, including diabetes, and the agents that scavenge free radicals may have great potential in ameliorating these diseases (Wilson et al., 1988). The most frequently encountered free radicals are the hydroxyl radical $\left(\mathrm{HO}^{\circ}\right)$, the superoxide radical $\left(\mathrm{O}_{2} \bullet-\right)$, the nitric oxide radical $(\mathrm{NO} \bullet)$ and the lipid peroxyl radical (LOO•) while non-free radical species principally being $\mathrm{H}_{2} \mathrm{O}_{2}$ and singled oxygen $\left({ }^{1} \mathrm{O}_{2}\right)$ (Yildirim et al., 2000). Dioscorea wallichii Hook.f. belongs to the family Dioscoreaceae and used as a major food supplements. It is found in India, Bangladesh, Burma, Thailand and China. 
It climbs on large shrubs or trees in mixed deciduous and evergreen montane forests. Tubers of $D$. wallichii are consumed on a local scale as a source of carbohydrates. They are eaten by ethnic groups such as the Sakai tribe, who live in the Banthad Range in Peninsular Thailand. These are also eaten by tribes in Orissa, India, during the winter months (Maneenoon et al., 2008). Rout and Panda, (2010) reported that, various tribal communities in Mayurbhanji district of Odisha using root extract of this plant for curing stomach pain. Till date there are no reports published about the phytochemical analysis and antimicrobial activity of the leaves extract of $D$. wallichii. Therefore this study was carried out to evaluate the phytochemical content, antioxidant and antimicrobial activity of different solvents extracts of the leaves of D. wallichii.

\section{MATERIAL AND METHODS}

\section{Plant material}

Leaves samples of $D$. wallichii plants were collected from Courtallum hills, Tirunelveli District, Tamil Nadu, India during the month of October 2015. The plant was identified and the herbarium specimen was prepared and deposited at Botany research laboratory, V.H.N.S.N. College (Autonomous) for future references.

\section{Preparation of leaves extracts}

The fresh leaves were air dried under fan and the leaves extracts were prepared by sequential extraction method using three organic solvents on the basis of the polarity of solvents (Acetone, Ethyl acetate and Methanol). 30g of the dried leaves sample was taken in a conical flask and $200 \mathrm{ml}$ of Acetone was added. The conical flask was kept on mechanical shaker for 24 hours, after that the extract was filtered through Whatman filter paper 1 and the pellet was allowed to drying and this pellet was used for the next solvent extraction (Ethyl acetate and Methanol). The dried extract was recovered and stored in refrigerator for further analysis.

\section{Phytochemical Screening \\ Preliminary Phytochemical Screening}

The leaves extracts of $D$. wallichii were qualitatively analysed to find out the presence of phenols, flavonoids, quinones, alkaloids, saponins, tannins, steroids, terpenoids, coumarins and catechins following standard methods (Kokate, 2000; Harborne, 1999; Edeoga et al., 2005; Harbone, 1973; Yadav et al., 2014 and Gopinath et al., 2012).

\section{Quantitative phytochemical analysis Estimation of total phenol content}

The amount of total phenol was determined using the Folin-Ciocalteu reagent method of Lister and Wilson, 2001. A standard curve was prepared by using gallic acid. Different concentrations of gallic acid were prepared in $80 \%$ methanol, and their absorbance was recorded at $760 \mathrm{~nm}$. 100 $\mu$ l of sample was dissolved in $500 \mu \mathrm{l}$ of Folin-Ciocalteu reagent (1/10 dilution) and $1 \mathrm{ml}$ of distilled water. The contents were mixed and incubated at room temperature for $1 \mathrm{~min}$. After $1 \mathrm{~min}, 1.5 \mathrm{ml}$ of $20 \%$ sodium carbonate solution was added. The final mixture was shaken well and incubated for $2 \mathrm{~h}$ in the dark at room temperature. The absorbance of all samples was measured at $760 \mathrm{~nm}$ using a UVVis spectrophotometer. The results were expressed in $\mathrm{mg}$ gallic acid equivalents (GAE) per milligram of dry weight of the plant.

\section{Estimation of total flavonoid content}

The flavonoid content in the extract was determined spectrophotometrically by the method of Quettier-Deleu et al., 2000. This method was based on the formation of a complex, flavonoid-aluminium, with the absorbance maximum at $430 \mathrm{~nm}$. Rutin was used as standard to make the calibration curve. $1 \mathrm{ml}$ of diluted sample was separately mixed with $1 \mathrm{ml}$ of $2 \%$ aluminium chloride methnolic solution. After incubation at room temperature for $15 \mathrm{~min}$, the absorbance of the reaction mixture was measured at $430 \mathrm{~nm}$ in a UV-Vis spectrophotometer. The flavonoid content was expressed in $\mathrm{mg}$ per $\mathrm{mg}$ of rutin equivalent (RE).

\section{Free Radical Scavenging Ability (DPPH)}

The scavenging ability of methanol extract on 1, 1diphenyl-2-picrylhydrazyl free radicals was estimated according to the method of Shimada et al., (1992). This method depends on the reduction of purple DPPH to yellow colored diphenyl picryl hydrazine. $2 \mathrm{ml}$ of various concentrations $(10-100 \mu \mathrm{g} / \mathrm{ml})$ of test sample was mixed with $0.5 \mathrm{ml}$ of $0.005 \mathrm{M}$ DPPH in methanol. An equal amount of methanol and DPPH served as a control. The mixture was shaken vigorously and then steadily kept for $30 \mathrm{~min}$ at room temperature in dark. The absorbance of the resulting solution was measured at $517 \mathrm{~nm}$ against a blank using UV-Vis spectrophotometer. The experiment was performed in triplicates. The DPPH radical scavenging activity was calculated by the following equation;

\section{$\%$ DPPH radical scavenging activity $=\left(\mathbf{A}_{0}-\mathbf{A}_{1}\right) / \mathbf{A}_{0} \times 100 \%$}

Where $A_{o}$ is the absorbance of the control reaction and $A_{1}$ is the absorbance of the sample of the tested extracts. Percentage of free radical activity was plotted against the corresponding antioxidant substance concentration to obtain the $\mathrm{IC}_{50}$ value, which is defined as the amount of antioxidant substance required to scavenge the $50 \%$ of free radicals present in the assay solution. $\mathrm{IC}_{50}$ values are inversely proportional to the antioxidant potential.

\section{Antimicrobial activity}

Extracts were screened against six bacterial species: Bacillus cereus (GRIBI01), Pseudomonas aeruginosa (GRIBI04), Staphylococcus aureus (GRIBI05), Escherichia coli (GRIBI06) Klebsiella terrigena (GRIBI08), Micrococcus mucilaginosus (GRIBI09) and a fungus Candida albicans (GRIBI03). All strains were obtained from the Department of Biology Gandhigram Rural Institute, Dindigul. The test organisms were maintained on nutrient 
agar slant and kept in a refrigerator at $4^{\circ} \mathrm{C} .100 \mathrm{ml}$ aliquots of nutrient broth were inoculated with the culture of test microorganisms using a loop and then incubated at $37^{\circ} \mathrm{C}$ for $24 \mathrm{hrs}$. Antimicrobial activities of methanol, ethyl acetate and acetone fractions of $D$. wallichii were carried out using the agar well diffusion method. Mueller-Hinton agar medium (MHA) was used for antimicrobial susceptibility tests. The MHA medium was prepared by pouring $20 \mathrm{ml}$ of molten media into sterile Petri plates. The plates were allowed to solidify and $100 \mu 1$ of an overnight broth culture of test micro-organisms was swabbed uniformly on the medium and allowed to dry for $5 \mathrm{~min}$. For agar well diffusion method, four equidistant wells $(6 \mathrm{~mm}$ in diameter) were cut from the agar with the help of a cork-borer. $40 \mu \mathrm{l}$ of leaves extracts (methanol, ethyl acetate and acetone extracts) containing $4 \mathrm{mg}$ concentration was loaded on $6 \mathrm{~mm}$ well. The standard antibiotic disc Gentamicin (10 mcg/disc) was placed on the surface of the plates. The plates were kept for incubation for 24 hrs at $37^{\circ} \mathrm{C}$. The zone of inhibition was measured around the well containing samples and standard. The experiments were performed in triplicates.

\section{Statistical analysis}

All the data was reported as mean \pm standard deviation of three replicates. The $\mathrm{IC}_{50}$ values were calculated using the $\mathrm{ED}_{50}$ plus v 1.0 programme. Statistical analysis was performed using Microsoft Excel.

\section{RESULTS}

\section{Preliminary phytochemical analysis}

The results of phytochemical analysis of leaves $D$. wallichii showed the presence of alkaloids, flavonoids, coumarins, phenols, tannins, saponins, terpenoids, quinones and catechins. The phytoconstituents steroids, quinones and catechins were not reported in any of the plant extract. All the extracts were reported to show positive result in color reaction only for alkaloids, flavonoids and saponons. Acetone and Ethyl acetate extract no responsible to the quinones, catechins and coumarins colouring tests. The phytochemical constituents of the plants investigated are summarized in Table 1.

Table 1: Phytochemical characterization of extracts from the leaves of $D$. wallichii.

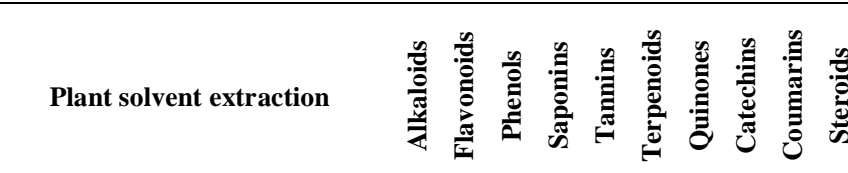

\begin{tabular}{lllllllllll}
\hline Acetone & + & + & + & + & - & - & - & - & - & - \\
Ethyl acetate & + & + & + & + & + & - & - & - & - & - \\
Methanol & + & + & + & + & + & - & - & + & - \\
\hline$+=$ indicates presence of phytochemicals, & $=$ \\
phytochemicals. &
\end{tabular}

\section{Total phenol and flavonoid content}

Table 2. shows total content of phenolic compounds in the studied plant extracts expressed in equivalent of gallic acid $\mathrm{mg} / \mathrm{mg}$ of plant extract. The highest amount of phenolic compounds $(0.486 \pm 0.098 \mathrm{mg} \mathrm{GAE} / \mathrm{mg})$ was found in the ethyl acetate extract and compared with other samples, whereas the acetone extract contained the lowest level of TPC $(0.190 \pm 0.02 \mathrm{mg}$ $\mathrm{GAE} / \mathrm{mg}$ ). The level of flavonoids, expressed in Rutin equivalents (REq) in $\mathrm{mg} / \mathrm{mg}$ of plant extract, varied from $0.212 \pm 0.024 \mathrm{mg} \mathrm{REq}$ $/ \mathrm{mg}, 0.201 \pm 0.023 \mathrm{mg} \mathrm{REq} / \mathrm{mg}$ and $0.144 \pm 0.006 \mathrm{mg} \mathrm{REq} / \mathrm{mg}$ in methanol, ethyl acetate and acetone extracts. The highest amount was found for the methanol extract.

Table 2: Quantitative phytochemical analysis of three solvent extracts of $D$. wallichii.

\begin{tabular}{cccc}
\hline $\begin{array}{c}\text { Phytochemicals } \\
\text { constituents }\end{array}$ & $\begin{array}{c}\text { Methanol } \\
\text { extract }\end{array}$ & $\begin{array}{c}\text { Acetone } \\
\text { extract }\end{array}$ & $\begin{array}{c}\text { Ethyl acetate } \\
\text { extract }\end{array}$ \\
\hline $\begin{array}{c}\text { Phenols } \\
\text { (mg GAE/mg) }\end{array}$ & $0.268 \pm 0.081$ & $0.190 \pm 0.02$ & $0.486 \pm 0.098$ \\
$\begin{array}{c}\text { Flavonoids } \\
\text { (mg GAE/mg) }\end{array}$ & $0.212 \pm 0.024$ & $0.144 \pm 0.006$ & $0.201 \pm 0.023$ \\
\hline Each value represents Mean \pm SD of three replicates. &
\end{tabular}

\section{Antioxidant activity}

Figure 1. shows result of the methanol extract exhibited the highest radical scavenging activity with $68.82 \%$ at $100 \mu \mathrm{g} / \mathrm{ml}$. The results revealed significant free radical scavenging activity of methanolic leaf extracts of $D$. wallichii on DPPH with $\mathrm{IC}_{50}$ value of $33.06 \mu \mathrm{g} / \mathrm{ml}$. The positive control ascorbic acid showed the $\mathrm{IC}_{50}$ values of $33.09 \mu \mathrm{g} / \mathrm{ml}$. According to these results, it was concluded that plant extracts from D. wallichii have potent antioxidant activity.

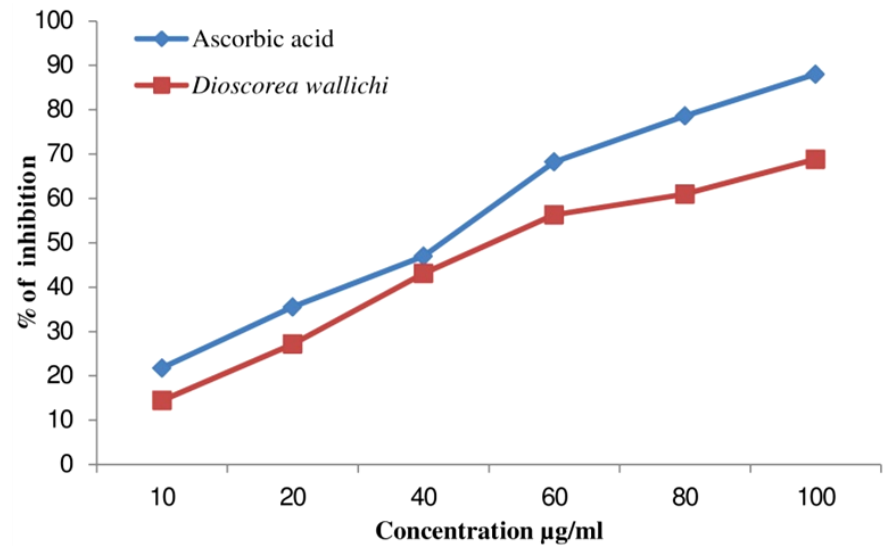

Fig. 1: DPPH free radical scavenging activity of crude methanol extracts $D$. wallichii.

\section{Antimicrobial Activity}

The antimicrobial activity of methanol, ethyl acetate and acetone leaf extracts at $4 \mathrm{mg} / \mathrm{ml}$ concentrations of $D$. wallichii leaves extracts against some of the test organisms: Gram positive bacteria, Gram negative pathogenic bacteria and fungus are presented in Table 3. The methanol extract showed the potent inhibitory effect against E. coli $(17.67 \mathrm{~mm})$ and $S$. aureus $(18 \mathrm{~mm})$ compare to positive control. Methanol and ethyl acetate extract did not show any inhibitory effect against $C$. albicans. Acetone extract showed minimum antimicrobial activity against all test microbial organisms with zone of inhibition range of $9-18.33 \mathrm{~mm}$. 
Table: 3. Antimicrobial activity of three solvent extracts from the leaves of $D$. wallichii.

\begin{tabular}{|c|c|c|c|c|}
\hline \multirow{2}{*}{ Microbial strain (species) } & \multicolumn{4}{|c|}{ Solvent Extracts (Zone of (Inhibition) in mm) } \\
\hline & Methanol & Ethyl acetate & Acetone & Gentamicin \\
\hline Bacillus cereus & $15.67 \pm 1.15$ & $11.00 \pm 1.73$ & $14.00 \pm 0.00$ & $14.33 \pm 1.52$ \\
\hline Klebsiella terrigena & $8.18 \pm 1.16$ & $10.00 \pm 0.00$ & $15.00 \pm 1.41$ & $25.00 \pm 0.82$ \\
\hline Candida albicans & $0.00 \pm 0.00$ & $0.00 \pm 0.00$ & $18.33 \pm 0.57$ & $12.00 \pm 1.73$ \\
\hline Pseudomonas aeruginosa & $11.33 \pm 0.94$ & $17.33 \pm 0.47$ & $9.00 \pm 0.00$ & $20.00 \pm 0.00$ \\
\hline Staphylococcus aureus & $18.00 \pm 1.52$ & $9.00 \pm 0.00$ & $12.00 \pm 1.52$ & $16.30 \pm 0.57$ \\
\hline Escherichia coli & $17.67 \pm 0.47$ & $10.00 \pm 0.00$ & $17.00 \pm 0.00$ & $17.33 \pm 0.47$ \\
\hline Micrococcus mucilaginosus & $15.66 \pm 0.57$ & $9.66 \pm 0.57$ & $12.66 \pm 0.57$ & $16.00 \pm 1.73$ \\
\hline
\end{tabular}

Each value represents Mean \pm SD of three replicates.

\section{DISCUSSION}

Phytochemical constituents in the plant samples are known to be biologically active compounds and they are responsible for different activities such as antioxidant, antimicrobial, antifungal, and anticancer (Hossain and Nagooru, 2011; Suresh and Nagarajan, 2009). Phenolics have antioxidative, antidiabetic, anticarcinogenic, antimicrobial, antiallergic, antimutageneic, and antiinflammatory activities (Saidu et al., 2012; Sasikumar et al., 2010). These flavonoids also have antioxidant property as they inhibit oxidative and hydrolytic enzymes, have impact on radical scavenging, anti-inflammatory and anti-cancerous activity (Liu et al., 2008; Alsabri et al., 2013). The present study carried out phytochemical analysis on the medicinal plant extracts revealed the presence of medicinally active constituents. Previous report suggest the presence of following compounds: phenol, flavonoid, tannin and alkaloid in the Dioscorea alata (Das et al., 2014). Our phytochemical analysis of the leaves extracts of Dioscorea wallichii revealed similar results to previous findings. Phytochemical constituents such as alkaloids, glycosides, reducing sugar, flavonoids, tannins, saponins, and several other organic compounds are secondary metabolites of medicinal plants that serve as defense mechanism against many microorganisms and insects (Bonjar et al., 2004).

From the dose dependent response curve of DPPH radical scavenging activity of $D$. wallichii, it was observed that the methanol extract had higher radical scavenging activity. . In addition to this, the $D$. wallichii tested all the (acetone, ethyl acetae and methanol) extracts contains a significant amount of total phenols and flavonoids, which play a major role in controlling free radical formation. Our work on the DPPH radical scavenging activity of $D$. wallichii agrees with the findings of Rajalakshmi and Mohan 2013 on the DPPH radical scavenging of $D$. tomentosa.

These results are highly correlate with the previous reports on the medicinal plants Dioscorea esculenta (Thajunnisha Begum et al., 2013). Based on earlier reports, secondary metabolites found in plants are phenols and terpenoids which represent the main antimicrobial agents. Similarly, aromatic compounds such as phenolic acids, alkaloids and flavonoids have also been identified as antimicrobial agents (Siddiqui et al., 2009). The present study also showed the significant antimicrobial activities against the tested bacterial and fungal organisms due to the presence of high amount of phenol and flavonoid compounds present in the leaves of $D$. wallichii.

\section{CONCLUSION}

In conclusion, D. wallichii contain potential antimicrobial and phytochemical components that may be of great use for the development of pharmaceutics as a therapy against various diseases. This plant crude extracts could serve as potential sources of new antimicrobial and antioxidant agents.

\section{ACKNOWLEDGEMENT}

Financial support and sponsorship: The corresponding author is grateful to University Grants Commission, New Delhi for providing financial assistance under Research Award Scheme.

Conflict of Interests: There are no conflicts of interest.

\section{REFERENCES}

Alsabri SG, El-Basir HM, Rmeli NB, Mohamed SB, Allafi AA, Zetrini AA, Salem AA, Mohamed SS, Gbaj A, El-Baseir. Phytochemical screening, antioxidant, antimicrobial and anti-proliferative activities study of Arbutus pavarii plant. J. Chem. Pharm. Res, 2013; 5(1): 32-36.

Bonjar GHS, Nik AK, Aghighi S. Antibacterial and antifungal survey in plants used in indigenous herbal medicine of south east regions of Iran, J Biol Sci, 2004; 4: 405-412.

Das A, Chaudhuri D, Ghate NB, Mandal ACN. Phytochemical analysis, antioxidant and anticancer potential of leaf extracts from edible greater yam, Dioscorea alata L., from north-east International Journal of Phytopharmacology, 2014; 5(2): 109-119.

Devasagayam TPA, Tilak JC, Boloor KK, Sane KS, Ghaskadbi SS and Lele RD. Free radicals and antioxidants in human health: Current status and future prospects. J. Assoc. Physicians India 2004; 52:794-804.

Edeoga HO, Okwu DE Mbaebie BO. Phytochemical constituents of some Nigerian medicinal plants. Afr J Biotechnol, 2005; 4: 685-688.

Gopinath SM, Suneetha TB. and Mruganka VD. Chemical prophylaxis and antibacterialactivity of Methanolic and aqueous extracts of some medicinal Plants against bovinemastitis. International Journal of Advanced Biological Research, 2102; 1 (1): 93-95

Grassi D, Desideri G, Tiberti S, Ferri C Oxidative stress, endothelial dysfunction and prevention of cardiovascular diseases. Agro Food Industry Ii-tech, 2009; 20: 76-79.

Harbone JB. Phytochemical Methods, Chapman \& Hall, London, 1999: 60-66.

Harbone JB. Phytochemical methods, Chapman and Hall, Ltd, London, 1973: 188.

Hossain MA, Nagooru MR, Biochemical profiling and total flavonoids and contents of leaves crude extract of endemic medicinal 
plants Corydyline terminalis L Kunth. Pharmacognosy Journal, 2011; 3(24): 25-29.

Kaur K, Arora S, Kumar S, Nagpal A Antimutagenic activities of acetone and methanol fraction of Terminalia arjuna. Food Chem.Toxicol, 2007; 40: 1475-1482.

Kim H, Park SW, Park JM, Moon KH, Lee CK. Screening and isolation of antibiotic resistance inhibitors from herb material Resistant Inhibition of 21 Korean plants. Nat. Prod. Res, 2005; 1: 50 - 54.

Kokate CK. Practical Pharmacognosy, Vallabh Prakashan, Delhi 2007: 107-111. $815-817$.

Krinsky N. I. Carotenoids as antioxidants. Nutrition, 2001; 17:

Lister E, Wilson P. Measurement of total phenolics and ABTS assay for antioxidant activity (personal communication). Crop Research Institute, Lincoln, New Zealand, 2001.

Liu X, Zhao M, Wang J, Yang B, Jiang Y.. Antioxidant activity of methanolic extract of emblica fruit (Phyllanthus emblica L.) from six regions in China. J. Food Compos. Anal, 2008; 21(3): 219-228.

Maneenoon K, Sirirugsa P, Sridith K. Ethnobotany of Dioscorea L. Dioscoreaceae), a major food plant of the Sakai Tribe at Banthad Range, Peninsular Thailand. Ethnobotany Research and Applications, 2008; 6: 385-394.

Quitter DC, Gressier B, Dine J, Brunet C, Luyckx MC, Cayin J, Bailleu CF, Trotin F. Phenolic compounds and antioxidant activities of buckwheat hulls and flour. J Ethnopharmacol, 2000; 72: 35-42.

Rajalakshmi Mohan VR. In vitro antioxidant activity of Dioscorea tomentosa KOEN EX. SPRENG. Int J Pharm Pharm Sci, 2013; 4(2):

Rout SD, Panda SK. Ethnomedicinal plant resource of Mayurbhanj district, Orissa. Indian J Tradit Know, 2010; 9(1): 68-72.

Saidu AN, Mann A, Onuegbu CD. Pytochemical screening and hypoglycemic effect of aqueous Blighia sapida root bark extract on normoglycemic albino rats. Bri J Pharmaceu Res, 2012; 2: 89-97.

Sasikumar JM, Maheshu V, Aseervatham GSB, Darsini DTP. In vitro antioxidant activity of Hedyotis corymbosa (L) Lam aerial plants. Indian J Biochem and Biophy, 2010; 47: 49-52.

Shi H, Noguchi N, Niki E. Natural antioxidants. In J. Pokorny, N. Yanishlieva, \& M. Gordon (Eds.), Antioxidants in food Practical application, (1st ed). Cambridge: CRC Press Woodhead Publishing Ltd, 2001
Shimada K, Fujikawa K, Yahara $\mathrm{K}$ Nakamura $\mathrm{T}$. Antioxidative properties of xanthan on the autoxidation of soybean oil in cyclodextrin emulsion. J Agric Food Chem, 1992; 40: 945-948.

Siddiqui S, Verma A, Ahmad Rather A, Jabeen F, Mukesh K. Preliminary phytochemical analysis of some important medicinal and aromatic plants. Advan. Biol. Res, 2009; 3 (5-6): 188-195.

Stocker R, Keaney JF. Role of oxidative modifications in atherosclerosis. Physiol. Rev, 2004; 84: 1381-1478.

Suresh SN, Nagarajan N. Preliminary phytochemical and antimicrobial activity analysis of Begonia malabarica Lam. J. Basic appl. biol, 2009; 3(1\&2): 59-61.

Thajunnisha Begum A, Anbazhakan S Evaluation of Antibacterial Activity of the Mucilage of Dioscorea esculenta (Lour.) Burkill. International Journal of Modern Biology and Medicine, 2013; 4(3): 140-146

Walton NJ \& Brown DE. Chemicals from plants: Perspectives on plant secondary products. London: Imperial College press, 1999.

Wilson RL. Free radicals and tissue damage, mechanistic evidence from radiation studies. In: Biochemical Mechanisms of Liver Injury. Academic Press, NewYork, 1998; 123.

Yadav M, Chatterji S, Gupta SK, Watal G. Preliminary phytochemical screening of six medicinal plants used in traditional medicine. Int J Pharm Pharm Sci, 2014; 6(5): 539-542.

Yıldırım A, Mavi A, Oktay M, Kara AA, Algur ÖF, Bilalolu V. Comparison of antioxidant and antimicrobial activities of tilia, sage (Salvia triloba $\mathrm{L}$ ) and black tea (Camellia sinensis) extracts. J Agric Food Chem, 2000; 48: 5030-5034.

\section{How to cite this article:}

Irulandi $\mathrm{K}$, Geetha S, Mehalingam P. Antioxidant, antimicrobial activities and phytochemical analysis of leaves extracts of Dioscorea wallichii Hook.f. J App Pharm Sci, 2016; 6 (11): 070074. 